\title{
技術の進步と特許制度の問題点
}

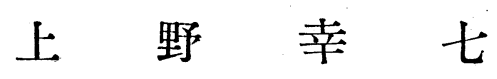

生產技術の改善をもたらす発明の意義は, 從來 生产された財貨をより能率的に 生產することによ り生產要素を他の用途に解放するか，または新た な財貨の生產を可能ならしめて新資源の用途を開 拓するにある。いずれの場合も発明は究極的に社 会の産出物の経済的效用を增加することに 泰仕す るものである。そこでこのような発明をうみだす 活動一これをかりにその経済社会の技術活動と なずける——はさにその社会の生產活動の一側 面にほかならない。特許制度は法制的側面からこ の技術活動を促進し, 組織化するものといえよう。

この技術活動というものは, 科学の進步, 経済 の発展に件ないおのずから 変化せざるを得ない。 ところがこの技術活動を容れる容器である特許制 度といらものは法律制度の特質として 固定的なも のである。ここに科学的, 経済的意味でいわれる 技術の進步および技術活動の変容と, その制度的 構造たる特許制度の矛盾がうまれてくる。このよ らな観点から現在特許廳で審議している特許制度 改正の要点をあとづけてみよう。

\section{I. 技術活動の対象と特許の対象}

このような技術の進步と 特許制度の間の矛盾と して，技術活動の対象である発明が，特許制度の 対象である「特許発明」の範囲によって常にすべ てをカバーされなかったという事実, および現在 の特許制度改正においてもなおこの点が 重要な改 正点の一つとなっているということを指摘するこ とができる。

1. 技術活動の対象 (発明) の拡大技術活動 の対象は技術の進步に件ない，不断に 拡大してき た。これは特許制度上特許される発明の 籍囲が拡 大されてきた歷史的経緯を背後から支えるもので ある。沿革的に特許発明の対象は次のような順序

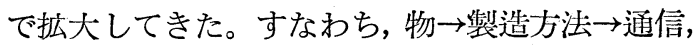
測定, 試驗方法（生產物を件なわない方法）＜wide>新用
途である。このほか, 化学物質, 医藥の特許を認 めるべきであるか，植物特許を認めるべきである かといら問題が考えられている。

「物」沿革的には特哔発明の対象は最初は物, 製作物であった。これボ近代工場工業の”発達，特 に化学工業の勃興に件ない, 生產物の製造工程に おいて高度の技術が必要とされるに至った。ここ に「物の製造方法」が新たに特許発明の対象とし て重要になったのである。日本の現行特許法第 35 條は, 「物の発明」および「方法の発明」の範疇 を認めている。ところでこの場合, 「方法の発明」 は必ず生產物を件ならがごとき規定の仕方をして おり，これに應じてわが國における特許制度初期 の運用も生產物を件なう方法, すなわち製造方法 にのみ特許を認めていた。

「生產物を件なわない方法」ところが電氣通 信方法や测定方法，試驗方法など，生產物を件な わないにかかわらず近代工業上重要な技術があり， この重要性が認識されると共にこのような技術発 明を特許することが認められるに至った。日本で は現行法上運用によって「方法の発明」でも生產 物を件なわない方法をも特許を認めるというやり 方でこれを認めているが，イギリスでは発明の定 義條文 (1949 年特許法第 101 條) で, 新たに試驗 方法，測定方法が特許されうる旨燳記したことに よってもこの閒の 経緯がらかがわれるであろう。

「新用途」さらに考えるべきは既知の物や方 法の新規な用途を発見した場合である。たとえば ある化学物質を創り出したときは，発明者はその 物質または製造方法について特許がとれる。しか し往ふにしてその性質について発明者もわかって いないことが多い。そこで後に至ってその知られ ていなかった性質が 新たにわかることがある（D DT などそのよい例である)。その新しく発明さ れた性質にもとづいて新たな用途を考えだした場 合に，これを特許してやるという考え方がある。 
1953 年アメリカ特許法はこの新用途（new use） の特許を明確に認めている條文 (第 100 條)を置 くに至った。しかし一方, 新用途は既知の物のも つ性質を應用したものにすぎないから特阡さるべ きでないという考え方も强く，イギリスではこれ を認めていない。わが國では從來これを認めてい なかったが，今次改正を機とし，このようなもの を保護することは技術の進步にマッチするであろ うと考えて，アメリカ法にならって新用途特許の 制度を探用することを考えている。

「植物特訢」発明が製造工業に 関する技窟の 冈容に限られるということは, 各國法とも暗默の うちに認めていた前提であるが，最近における農 産物品種の改良というものは單に生物学的な自然 的な現象でなく極めて人工的な 技術であり，技術 活動を廣く生產活動の一侧面として捉えれば，こ れは農業技術の一つとして考えることができる。

アメリカ特許法は 1930 年以來これを認め 1946 年迄に 700 件の特許がこの分野で認められた。日 本でもとりあげてはどうかという改正意見もあっ たが，これを採用する迄には至っていない。現在 この分野の保護を與えるものとして農産種苗法 (農林省所管) がある。

r化学物質, 医藥」現行法第 3 條は化学物質 および医藥の特許を認めず，從って從來は「製造 方法」としてのみ特訴されるにすぎなかった。こ れは日本の化学工業に対する産業政策的配虑 (化) 学物質に特許を與えて独占されることが化学工業 の発達を阻害しないか）および公衆衞生的見地 医藥に特許を與えると医師の投藥，藥㓮師の調藥 を不自由にする）によるものとされているが, 英, 米, 佛などの先進國では化学物質そのものの特許 を認めており，また医藥についてもなんらかの條 件附きではあるがこれを認めている國が多い。今 次改正に当っても，これを認めてはどうか，認め るとすればいかなる條件を必要とするか，という 点について檢討中である。

2. 技術活動の対象の複雜化初期の発明が 「物」に限定して考えて不都合でなかったのは，発 明は物そのものにあり，それをつくるプロセスは 單にマニュアルなものにすぎなかったからであ る。しかし化学工業の発達はこのような單純な発 明活動では満し切れぬ大規模な発明を必要とし た。一つの新しい化学物質をつくり出すには, そ
の製造裝置, 原材料, 中間材料, 反應藥, 製造條件 などを考えてゆかねばならない。この場合技術的 意味における発明活動は一つである。しかし,その 発明活動の対象は物あり, 方法あり, 装置ありで, そのため從來の特許法の扱いでは, 物の発明, 方法 の発明, 裝置の発明と三つの特許が許される。しか し根本的に発明思想は共通であり, 発明活動も一 体として把握される以上，これを一つの発明と考 えることの方が晏当である。そこでこのような場 合從來と考え方を變え, 全部を一発明とみて特許 し(從って一特許権が成立する), 生產物, 裝置, 方法は特許の請求範囲に别項に分けて記載し 権利 範囲を明確にしてゆくという制度（これは英, 米, 独などに共通する制度で多項制とよばれる）を採 用することが今次改正で探りあげられている。

\section{II. 技術進步に伴なう技術活動 の態樣の変化と特許制度}

技術進步に件ない技術活動の態樣も変化しこれ が次の諸点において制度改正にとりあげられた。

1. 技術活動の組織化, 社会化 技術活動が 社会の生產活動の一部を担当するものとなった結 果, 技術活動が社会化, 組織化されてきた。この ため技術活動相互におりる連絡, 技術情報の卒換 ということが必須となり，街の発明家が散発的， 偶然的に発明をするということは社 会的に組織化 された発明活動担当者——会社, 團体の研究所, 大学などが相互に技術情報を交撸しあって連絡協 同しながら活動して発明をするといらことが発明 活動の大きな部分を占めるに至った。このような 点にかんがみ，制度改正では次の二点がとりあげ られた。

（イ）発明を研究者が学会発表㧍よび㺫行物発 表した場合，新規性䘫失の例外を認めること（現 行特許法第 5 條に附加)。ここれは技術情報の交 掺の必要性と特許の要件たる新規性一一公知なら ざること——との調和である。從來は研究者が自 分の発明を含む研究を学会で発表したり, 刊行物 に論文としてのせると，特許法上公知であるとし て特許されない。そこで発表後一定期間以內にそ の発明を特許出願したときは，新規性あるものと みなして救済するための規定を新たに設けたいと 考えている。

（口）勤務発明規定 (第 14 條) の改正技 
術活動の担い手が組織化し，このような場合発明 はその組織体に帰せらるべきであるという考え方 もある(法人発明の理論)。しかし現行特許法抢よ び各國の法制の多くは，発明者は自然人であると の立前を持つ。そこで会社, 法人, 國などに㕍傭 されている研究者が発明をしたときも特許をうけ る権利は第一次的に注被傭者たる研究者に帰す る。しかし使用者の会社，法人，國が資金を投じ 設備を提供し研究者の給與を拂っている点も無視 でぎない。今次改正ではこのような使用者の貢献 度と研究者個人の貢献度を比較考量の上で，いず れに特訢をらける権利を帰属せしめるべきかを從 來の規定より明確にすると同時に, 発明者たる研 究者個人については特許をうける権利を持たない 場合に，実質的に十分な金銭的補償をらけられる ように補償金関する規定を充実して，研究者の 保護をはかることが重要な閣題としてとりあげら れている。

\section{2. 技術進步の速度 (技術速度) の急速化}

現在特許権の存続期間は出願公告後 15 年である。 しかし出願してから公告する迄審查を経なければ ならない。この寒查が現在 1 年 2 年と長くかかる ので各國共悩んでいる狀態である。ところが技術 の進步と共に技術更新の速度も速くなってきたの で， ある発明を出願し審查に 1 年 2 年を費や寸間 に, 技術水準の向上はその発明のレべルを拔いて しまう。その場合に審查がすんで出願公告をして も，それにはそのときの技術水準以下のものを公 告しただけで技術公開といら見地からは意味がな いし，かえってこれを特許することは技術の進步 を阻害するだけのものである。そこでこのような 不都合を生じさせないよう審查の期間を法律で定 めて，審查の促進をはかりたいと思っている。

\section{3. 技術活動の幅が拡からったこと技術の進} 步に伴ない日常の技術活動の幅も搪がってきてい る。このため通常の技術者が既知の 技術的知識を 本生活用する場合に，その應用のできる籍囲も廣 くなった。発明が單に新規であれば特許するとい らことであると，既存の技術知識から普通の 技術 者なら容易に類推して應用できるような程度の技 術が新しいというだけで特許されてしまう。これ は技術の進步を獎励するよりも，むしろ阻害する だけにすぎない。そこでこのような場合を特許か ら除外することが必要である。アメリカ，イギリ
スでは法律でこのための措置を明定しているが， わが國では從來このような発明は「発明を構成し ない」ということで特許を認められないといら運 用であったが，これを法制上明確にしてゆくこと を考えている。

\section{III. 技術進步からみた技術の 財産的價值と特許権侵害}

新しい技術, 発明が総体としての経済社会の生 產活動において占める意義はこの論文のはじめに おいて述べたでとくであるが，これを経済社会內 の個及の企業についてみると，ある特定企業にお ける新技術の導入は以前と同量の生產要素を用い てその企業における産出量を增加する。いかば一 企業における新技術，発明の導入はその企業の生 産性を向上し，その企業の企業收谷を增大するも のである。このような新技術，発明に特許権が 與 えられている場合には，もし権利者以外の企業主 体がその新技術，発明を許可なく使用すれば特許 権侵害といら問題を生ずる。特許権侵害の法的救 済として現行特許法は第 129 條で侵害罪の罰則を 規定しているが，民事上の救済についてはなんら 規定していないので，民法の損害賠償請求（不法行 爲) 差止哧求権の規定を類推適用しているにすぎ ない。しかし特許権の內容たる発明の特質, 特に その経済的機能からみるとこのような民法の規定 の逼用では具体的に妥当でない面も多いので, こ れを次の諸点を中心に改めてゆきたいと思ってい る。

（イ）損害瞕償 民法上の不法行急に 基づく 損害賠償請求権の制度が特許権侵害に適用された とき，問題となるのは損害賠償額の算定がむづか しいことである。ことに他人の特許権を使用する ことは特詥権者に 何程の損害を與えるかといらこ とがよくわからない。しかし特訢権の內容たる発 明を使用寸れば，それを使用した企業敒企業利益 を增加させるものである。そして他人の特許権を 使用すればその実施者は特許権者に対價として実 施料を拂らのが通常である。すれば特許権者が特 許権を侵害されたとき蒙る損害とは，この実施料， ロイヤリティといらものが最低のものとして考光 られるのである。英米の法制ではこの点に注目 し，損害賠償額の算定に当っては実施料を基準と

(157ページへつづく) 


\section{8. 塭田 用}

本邦の塩田の構造を簡單に說明すると, 粘士を踏み固 めてつくり，その傾斜上に砂をまいて，海水を緩流して 太陽熱により永分 蒸発を行うもので あるが, 粘土は塩 承范若干吸水し， その損失は無視で きないので, 粘土 の代りに PVC フ ィルムを使用して 損失を防ぐ方法が 專賣局を中心とし て研究が淮めら れ，方法そのもの は期待通りの成果 を得ているようで あるが，問題はフ

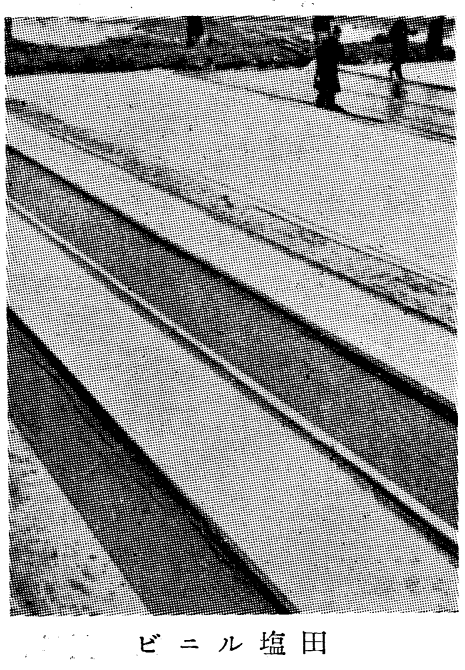

イルムの耐久力である。前述の溫床用などよりも遥かに 强い太陽光線に当て，長期間の使用に耐光叔ばならない ので,メーカーはこの点に大きな努力を拂い，專賣局自 体もこの研究のために Weatherometer 眺入し, 同局 研究所で連続 $500 \mathrm{hr}$ にわたる試驗を行い, これに合格 したフィルムは実用時 500 日近い耐久力のあるものとし て大々的们用せんとしているようである。

海水はあらゆる物質を溶存し, 日光による影響も苛酷 であるので, PVCフィルムに含まれる安定剤が後者の光 分解をいかに防ぎ, 可塑剤が前者の藥品でどの程度侵さ
れないのか詳しいデータを持たないので適切な批制はで きないけれども，連続実用試臉をさらに継続しないと明 確な断定が下されない用途であらう。

\section{9. 結 言}

以上, ここ 2,3 年の間に急激な用途開拓に成功した溫 床用ビニルをはじめとして, 目下研究中の農業用, 塩田 用フィルム迄一通りの解說を行ったが, 些業用の消費量 は予想外に大きく, 塩化ビニル協会の本年頭初の消費推 定はPVCだけで 2,300 トン6)達し, 全需要の 1 割近 くが見込まれているほどである。

しかし一方ビニル・ハウス経瞼者の中には, 耐久性の 点などから，ビニル・八ウスで儲けたら完全なガラス溫 室をつくりたいと考劣る人もあり，農民の批制は酷しい ようである。けれども資源の乏しい本邦では尿素樹脂と 共に PVC は原料的にもっとも惠まれた合成樹脂であ り, 日本大の発案で農業用のような独自の用途を開拓し てゆく道こそ國力增强の捷径であり, 本稿には割愛した が，海流の移動を調べるためにビール瓶に代えてビニル 袋を使用するなどの使用量は少くても道切な用途が次々 に見つけられて行くであろう。(東京農工大教授・工博)

\section{文献}

1) 筆者：化学と工業, 6, 285 (昭 28)

2) 例えば佐藤止才夫：高分子, 3,184（昭 29）

3) Plastics World, 4, Feb. (1954)

4) 筆者： 樹脂加工, 2, 480 (昭 28)

5）農林省編纂：宸民丵書， 88 号（稻のビニル苗代の作 り方）(昭 29)

6） PVC 協会 “ビニール工業有成要望書” (昭 29)

7）稻川微：プラスチックス 6,2,1 (昭 30)
(153 ページよりつづく)

している。改正に当っては，わが國でもこの点を とりあげて考えてゆきたいと思っている。

（口）損害賠償がとれるには民法では権利者が 侵害者の故意過失を立証せねばならないが，これ は権利者にとり, 重きにすぎる負担であるので, 企 業の報償責任の考え方から挙証責任を轉換しては どうかという点も考慮中である。

（八）不当利得 ある企業が他人の特許権を 侵害して莫大な利益をあげても，権利者はわずか な損害賠償額しかとれず，その余りは侵害者の手 訢に残る場合も多いと考えられる。これでは公本 でないので, このような利得が生じたらこれを特 許権者の方へ移すのがよいのでないか，この利得 について不当利得返還請求権を特許権者に認めて はどうかということも檢討すべきであろう。

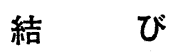

その他技術活動と生產の結びつきを特許制度の 上から考えるものとして，実施許諾用意制度など も改正においてとりあげられている。これらにつ いては, 詳しくは工業所有権制度改正審議会の答 申を得てから公表せられ，いずれ社会各方面の批 刵檢討をうけるべき問題である。しかし，從來單 に法律制度としての精巧さ, 体系を誇り, またその ような観点からもっぱら制度改正が考えられてき たのに対し，今後重視すべきは特許制度と社会の 経済活動との結びつきを改めて考え直し, 経済社 会の進運の向うところを見極めてその方向への指 導的立法を行わねばならないのではないかという ことである。この小諭文の功罪もこのような観点 からみていただければ幸いである。（特許廳長官） 